\title{
As metamorfoses do império e os problemas da monarquia portuguesa na primeira metade do século XVIII*
}

\section{The empire's metamorphoses and the problems of the Portuguese monarchy in the first half of $18^{\text {th }}$ century}

\author{
RICARDO DE OLIVEIRA \\ Doutor em História Social - UFRJ/PPGHIS. \\ Professor da UFRRJ / Universidade Federal Rural do Rio de Janeiro \\ Rodovia BR 465, Km 07, Seropédica - Rio de Janeiro \\ rdoclio@ufri.br
}

RESUMO Durante a primeira metade do século XVIII, em diversas dimensões do mundo português, operou-se um significativo processo de metamorfose, tanto no âmbito interno do reino quanto na própria configuração mais geral do Império. Lisboa, consolidada como caput regne, começou a viver significativa transformação. No pensamento de diversos personagens ligados à administração da monarquia havia a certeza de que o eixo do Império situava-se definitivamente no complexo atlântico, nas duas margens

Texto recebido em: 10/05/2009. Aprovado em: 18/07/2009. 
do oceano. Este artigo tem por objetivo discutir algumas questões relativas a esses fenômenos.

Palavras-chave império português, dom João V, corte, Lisboa

ABSTRACT During the first half of the $18^{\text {th }}$ century, in various dimensions of the Portuguese world, operated a significant process of metamorphosis, both within the kingdom itself as the more general setting of the Empire. Lisbon, consolidated as caput regne, began to live a significant transformation. In the mind of several characters related to the administration of the monarchy was not certain that the axis of the Empire was located permanently in the complex Atlantic, on both sides of the ocean. This article aims to discuss some issues related to this phenomenon.

Keywords Portuguese empire, dom John V, court, Lisbon

Baltasar abre a boca de espanto, vem duma aldeia e entra numa cidade, bem está que Lisboa seja o que é, nem poderia ser de menos a cabeça de um reino senhor do Algarve, que é pequeno e perto, mas também doutras partes grandes e distantes, que são o Brasil, África e Índia, mais uns tanto lugares avulsos pelo mundo, bem está, digo, que seja Lisboa aquela desmedida e confusão...

José Saramago, Memorial do Convento.

Não poucas vezes, a ficção permite que se vislumbrem grandes verdades acerca da experiência histórica do homem. No caso do trecho destacado como epigrafe desse artigo, por meio da prosa densa do narrador construído por pelo escritor José Saramago, temos a fala do personagem Baltazar Mateus, apelidado por Baltazar Sete-Sóis, por assim dizer, um dos "heróis" trágicos do romance Memorial do convento, obra que explicitamente e de forma profunda flerta com as fronteiras entre a narrativa histórica e a narrativa ficcional. A fala de Baltazar nos levar a imaginar que seria possível a um observador mais atento, vivendo no Portugal da primeira metade do Século XVIII, perceber um conjunto de transformações e problemas operados tanto no âmbito interno do reino quanto na própria configuração mais geral do próprio Império. Era o "mundo" português que não cabia somente no pequeno reino peninsular. Havia ainda a Índia, muito mais um sonho do que realidade. E havia o Brasil e a África que, embora divididos pelo imenso rio oceânico, eram então o coração econômico da monarquia.

Todavia, durante muito tempo estigmatizado pela historiografia, podemos dizer que o longo reinado de dom João V (1707-1750), cenário histórico em que se desenvolve o romance, caracterizou-se por conhecer várias transformações tanto no plano interno ao reino quanto em relação 
à configuração de seu vasto império colonial. Lisboa, cuput regne de toda a monarquia, vive então plenamente os significados de capitalidade, ao passo que Portugal definia-se enquanto um reino de segunda grandeza, mesmo possuindo esse vasto Império. Neste ínterim, praticamente todas as atenções dos homens de Estado direcionaram-se agudamente os domínios ultramarinos que, afinal, significava preservar a própria Monarquia. Este artigo pretende discutir tanto problemas historiográficos relativos às interpretações sobre o reinado de dom João $V$ quanto apontar para possibilidades de investigação sobre temáticas relativas à própria reconfiguração do Império português no período. Além disso, é nossa intenção analisar alguns aspectos relacionados ao processo mais amplo que constituição definitiva de Lisboa como cidade-corte e centro da monarquia portuguesa.

\section{Caput regne: Lisboa e o "reinado do sol" na primeira metade do século XVIII}

Erguidas sobre o cume e se estendendo ao longo de sete colinas não muito elevadas, às margens do rio Tejo, o que lhe permitiu possuir um certo ethos de marítimidade, a cidade de Lisboa devia ser um lugar que mantinha ainda a fisionomia marcada pela presença secular de inúmeras hordas de ocupação. Do alto do morro mais alto estavam as ruínas do castelo de São Jorge, como que a lembrar ao observador um passado já distante de lutas contra os mouros. Quem caminhava pela cidade percebia que toda ela estava preenchida de ruelas estreitas e uma infinidade de ladeiras que dificultavam a passagem dos coches e carruagens com os fidalgos perambulando de-lá-para-cá. Como pequenos riachos descendo montanha, quase todos os caminhos confluíam para o terreiro do Paço da Ribeira, à beira do Tejo, que se constituíra no verdadeiro coração da cidade. Em 1554, Damião de Góis, no Elogio da cidade de Lisboa, dizia que ela, ao lado de Sevilha, era uma das verdadeiras rainhas dos oceanos. Ponto de partida para as conquistas da África e para a descoberta do novo caminho às Índias e do Brasil, Lisboa, cuja glória era ser cosmopolita, pois, por toda roda do ano, eram trazidas para esta cidade inúmeras coisas exóticas vindas da Índia, Pérsia, Arábia, Etiópia, Brasil, e África. ${ }^{1}$ Cerca de meio século mais tarde, já sob o domínio filipino, Luís Mendes de Vasconcelos não pouparia elogios à cidade de Lisboa na luta por demonstrar as vantagens que o rei teria em transformá-la em capital da monarquia hispânica. Mas, de fato, a cidadecorte de Lisboa somente a partir da Restauração viria assumir o status de capitalidade no âmbito da monarquia portuguesa² (caput regni), isto é, como

Ver GOIS, Damião de. Elogio da cidade de Lisboa. Porto: Guimarães Editores, 2002

2 GOUVEIA, António Camões. Estratégias de interiorização da disciplina. In: HESPANHA, António Manuel. (coord.) História de Portugal. O Antigo Regime (1620-1807). Lisboa: Estampa, 1992, p.415-416. 
o centro político, econômico e cultural do império luso. Nos primeiros anos dos setecentos, a cidade deveria possuir, no mínimo, 200 mil habitantes. Depoimentos de viajantes que conheceram a Lisboa joanina legaram-nos importantes impressões sobre ela. César de Saussure, que a visitou pelos idos de 1730, dizia que ela deveria ser uma das "mais belas e maiores da Europa". E, vista sob a perspectiva de quem chegava através do Tejo, Lisboa deveria encantar qualquer observador que nela procurasse porto seguro. A cidade era rodeada de campinas, casas de recreio, olivais, bosques e bosquetes repletos de laranjeiras e limoeiros, ${ }^{3}$ um ambiente bucólico que aproximava a dimensão rural da vida portuguesa daquele clima agitado e urbano possível a uma cidade européia no início do século XVIII. Pouco tempo antes, entre os anos de 1723 e 1726, o naturalista francês, Charles Fréderic de Merveilleux, fazia juízo semelhante sobre a mesma paisagem, relatando que dificilmente "se encontrará mais belo panorama no mundo", com exceção de Constantinopla, fazia questão de assinalar o naturalista. ${ }^{4}$

Do ponto de vista estrutural, havia certa marca de precariedade que evidenciava uma cidade com traços medievais, contrastando com a impressão de beleza que tinham os observadores quando chegavam à ribeira. $\mathrm{O}$ ordenamento das ruas e vielas era extremamente irregular; apontava para o caráter assimétrico do desenvolvimento urbanístico. Sem iluminação alguma durante a noite, os passeios noturnos pela cidade eram arriscados. A ausência de qualquer modalidade de organização sanitária tornava o ambiente, à primeira vista encantador, no mínimo nocivo à saúde. Um determinado observador anônimo, que deixou um relato sobre a cidade, anotou que se "corria o risco de ficar enxovalhado com as imundícies que são de uso despejarem das janelas às ruas, pois as casas não tinham latrinas". ${ }^{5}$ Mesmo que as riquezas advindas do ultramar possibilitassem certo crescimento urbano, principalmente em direção às freguesias vizinhas ao centro, a quantidade de construções foi, até certo ponto, modesta no período. Poucos foram os novos palácios erguidos na época, mesmo pelos grandes. ${ }^{6}$ Além disso, para um visitante mais acostumado aos modos de sítios como Paris, Roma ou Londres, a cidade não parecia ser tão aconchegante, pois faltavam hospedarias e botequins onde se pudesse viver certo clima mais cosmopolita. ${ }^{7}$ Sob diversos aspectos, a realidade da estrutura urbana de Lisboa era, por assim dizer, precária.

3 SAUSSURE, César de. Cartas Escritas de Lisboa no ano de 1730. Apud: CHAVES, Castelo Branco. (org.) O Portugal de D. João V visto por três estrangeiros. Lisboa: Biblioteca Nacional, 1983, p.263.

4 MERVEILLEUX, Charles Fréderic. Memórias Instrutivas Sobre Portugal. Apud: CHAVES, Castelo . (org.) O Portugal de $D$. João $V$ visto por três estrangeiros, p.133.

5 Descrição da Cidade de Lisboa, em 1730. Apud: CHAVES, Castelo . (org.) O Portugal de D. João V visto por três estrangeiros, p.39.

6 FRANÇA, José-Augusto. Lisboa antes do Terremoto de 1755. In: Lisboa pombalina e o lluminismo. Lisboa: Bertrand, 1977, p.35-42.

7 SAUSSURE, César de. Cartas Escritas de Lisboa no ano de 1730, p.266. 
A sociedade estava ordenada por clivagens hierárquicas rígidas. Esses mesmos observadores que lá estiveram foram unânimes em notar esse aspecto da constituição social de Portugal e seu mundo, emblematicamente presentes em Lisboa. Aspecto comum a outras monarquias modernas, o distanciamento do universo da aristocracia e da corte em relação ao resto da sociedade era algo que evidenciava a rígida hierarquização em que estava organizada a sociedade. Conforme notou um desses observadores, aos grandes (duques, marqueses e condes) o rei reservava o privilégio de escolher "as pessoas que hão de ocupar os principais cargos da corte, da guerra e dos governos ultramarinos". ${ }^{8}$ Esses agentes sociais constituíam o núcleo de poder aristocrático. Era a nobreza de sangue, acreditada como a mais antiga e tradicional. Esse grupo situava-se mais próximo do rei devido a honras obtidas em campanhas e lutas em defesa do reino. Mas, havia ainda os setores da nobreza recém-nobilitados, cujos títulos eram obtidos através de mercês, quer dizer, por graça e recompensa, e, por conta disso, considerados socialmente inferiores aos grandes do reino.

Nas demais esferas da vida urbana, relacionadas ao "povo", ou melhor, a gente miúda, a multiplicidade de tipos era evidente. Pelas ruas da velha cidade de Lisboa, havia a presença de negros e mestiços que se faziam notar com bastante frequência no dia-a-dia, reforçando a idéia de que, também no centro no império, havia uma quantidade bastante expressiva de homens negros livres e escravos. ${ }^{9}$ Outro traço da cidade que devia certamente chamar muita a atenção dos observadores era a existência de uma quantidade abundante de igrejas, conventos e outras construções de caráter eclesiástico, quase todos ricamente ornamentados, fazendo com que esta dimensão da cidade assumisse a primazia sobre as demais. ${ }^{10}$

Foi neste cenário que, em $1^{\circ}$ de janeiro de 1707 , no paço da Ribeira, se determinou para o auto de levantamento e juramento que deveriam fazer os grandes senhores seculares e eclesiásticos e demais súditos ao novo rei, coroado como dom João V. Assinalava-se um momento importantíssimo na história do Portugal restaurado. Consolidava-se efetivamente a nova dinastia, e se superavam, definitivamente, os momentos de crise sucessória que marcaram os reinados de seu tio e de seu pai, pouco após a Restauração, ${ }^{11}$ o que segundo a narrativa de um contemporâneo, Tristão da Cunha Ataíde, $1^{\circ}$ conde de Povolide, "Iuziram neste dia de tão universal

8 Descrição da Cidade Lisboa, em 1730, p.51.

9 Descrição da Cidade Lisboa, em 1730, p.55.

10 FRANÇA, José-Augusto. Lisboa antes do Terremoto de 1755, p.35-42.

11 Referimo-nos a crise que envolveu a sucessão de dom João IV, falecido em 1656. O sucessor, a principio, seria o príncipe Teodósio, mas este veio também a falecer três anos antes do pai. O sucessor passou a ser então o príncipe Afonso, coroado como Afonso VI (1643-1683). Os anos de seu curto reinado foram tumultuados e foram marcados por uma corte dividida. Casou-se, em 1666, com Maria Francisa de Sabóia, mas um ano mais tarde, após uma grande manobra política que envolveu a rainha e parte da nobreza, teve seu casamento anulado por não consumar núpicias. Acusado de incapacidade para governar, Afonso VI foi destituído do trono, assumindo seu lugar, como regente, o príncipe dom Pedro, que foi coroado rei em 1683, após a morte de Afonso VI. 
aplauso os diamantes e pérolas da nossa Índia Oriental, e o ouro das nossas minas do Rio de Janeiro dos Estados do Brasil". ${ }^{12}$ Entretanto, se no plano interno a situação encontra-se estável devido à política de dom Pedro II, o cenário do continente era desafiador para um país que há mais de meio século vinha lutando para manter sua autonomia política. Nesse sentido, para Portugal os problemas relativos à própria dificuldade de se manter como monarquia independente conduziu o país para o manto protetor da Inglaterra, aproximação que começou a se consolidar com o casamento da filha de dom João IV e dona Luísa de Gusmão, Catarina de Bragança (1638-1706), irmã de Afonso VI e Pedro II, com Carlos II, da Inglaterra, em 1662. ${ }^{13}$ Nesta conjuntura, Portugal se tornara uma monarquia periférica, tendo que se esforçar para manter, criar e gerir um espaço de neutralidade formal ante os diversos partidos, o que foi sempre praticamente impossível, visto que o alinhamento à Inglaterra, na maior parte das vezes, foi o que se conheceu. ${ }^{14}$ Os escritos de diplomatas e homens de estado, como José da Cunha Brochado, dom Luís da Cunha, conde da Tarouca e Sebastião de Carvalho e Mello e, é claro, Alexandre de Gusmão, em seu conjunto, fornecem um nítido panorama da difícil situação de Portugal frente a esses problemas, assim como encaminhavam propostas no sentido de superar os entraves mais difíceis. ${ }^{15}$

12 ATAÍDE, Tristão da Cunha (1 ${ }^{\circ}$. conde de Povolide). Portugal, Lisboa e a corte nos reinados de D. Pedro /l e D. João V. Memórias históricas do $1^{\circ}$. conde de Povolide. Lisboa: Chaves Pereira - Publicações, S.A., 1989, p.192.

13 O acordo de casamento ratificava a política de aproximação entre Portugal e Inglaterra que se fazia sentir desde a Restauração, em 1640. O rei de Portugal dotou a irmã com 2 milhões de cruzados, entregando ainda à Inglaterra a cidade fortaleza de Tanger, no norte da África, e o domínio sobre o porto e ilha de Bombaim.

14 Ver: NOVAIS, Fernando. Política de Neutralidade. In: Portugal e Brasil na crise do Antigo Sistema Colonial (17771808). São Paulo: Hucitec, 1982, p.17-56; MACEDO, Jorge Borges de. História diplomática portuguesa, constantes e linhas de força - estudo de geopolítica. Lisboa: Edição da Revista "Nação e Defesa", 1987.

$15 \mathrm{Em} 1^{\circ}$. de novembro de 1700, morria Carlos II de Espanha, não deixando descendência de nenhum de seus dois casamentos, o que determinou o fim do poder Habsburgo na Península Ibérica. Mesmo não sendo a Espanha o que fora nos áureos tempos de Felipe II (1556-1598), a disputa pela sucessão do trono implicava o poder sobre vasta área colonial, que compreendia imensos e riquíssimos territórios no Novo Mundo, enclaves na Africa e Ásia, encarniçadamente disputada pelas grandes potências da época. Além disso, tratava-se de uma das principais coroas européias, que dominava regiões na própria Europa, como Flandres e boa parte da Península Itálica. Em virtude disso, entre 1701 e 1712, as principais potências européias envolveram-se num conflito de largas proporções. A origem desse conflito adveio, fundamentalmente, da disputa entre duas coroas importantíssimas na Europa do período que se candidatavam a herdar o trono espanhol: de um lado posicionava-se o imperador Leopoldo, representante dos reis católicos, e defensor do direito de Carlos, arquiduque austríaco, herdeiro da coroa, e do outro lado havia os interesses de um príncipe francês, o duque de Anjou, neto de Luís XIV e Maria Teresa, irmã de Carlos II. Em tese, o testamento de Carlos II impedia a união da Coroa espanhola com qualquer outra, atendendo assim a qualquer objeção às suas pretensões de ter como sucessor um Bourbon. Na prática, a ascensão de Felipe de Anjou ao trono espanhol significava a realização de um projeto que há muito pensado pelo rei sol, isto é, formar um grande império continental na Europa. Obviamente que a outra grande da época, a Inglaterra, observava com temor a formação desse gigante bourbônico no continente. Assim, veio a guerra. As efemérides do conflito não nos cabem discutir aqui; porém, é significativo lembrar que seu desfecho tornou-se possível a partir do momento em que, em 1710, mesmo enfraquecido, Felipe $V$ conseguiu manter posições importantes como a das cidades de Brihuega e Villaviciosa, pontos importantes para a proteção de Madrid, e que possibilitavam fôlego para a invasão de Aragão e Catalunha. Por outro lado, foi de importância decisiva a morte do imperador Leopoldo, o que naturalmente conduziria o arquiduque Carlos da Áustria a restabelecer o grande império Habsburgo. Por certo, essa idéia jamais poderia interessar tanto à Inglaterra quanto à França. Com o final da guerra, reuniram-se em Ultrech as potencias beligerantes para pactuar os acordos de paz. A tutela inglesa possibilitou que Portugal conseguisse vantagens e garantias em relação à Espanha e França: o reconhecimento da posse do território da Colônia do Sacramento e a promessa de resolver as querelas sobre os limites portugueses e franceses na região amazônica foram duas importantes conquistas. Sobre essa questão, ver ALMEIDA, Luís Ferrand de. A Colônia 
Todavia, em 1716, ocorreu um fato de suma importância e que marcaria tentativa de centralização do poder que se verificou durante o reinado de dom João V: a criação do patriarcado de Lisboa, com subseqüente divisão da cidade em ocidental e oriental, tornando-se referência obrigatória em qualquer documentação oficial o registro dessa partição a partir daquele momento. A sé patriarcal ficava localizada nas dependências da capela real, na extensão do palácio real, na Ribeira. Observe-se que, conforme assinalou Ana Cristina Araújo, este evento foi um marco importante, "um passo decisivo na ampliação do código ritual de comunicação entre o rei e os seus súditos", pois, através desta fundação, "conseguida à base de dispendiosas campanhas diplomáticas junto a Santa Sé, dom João V ia alargando seu poder" ${ }^{16}$ Em suma, como cidade sede da corte do reino e do império português, Lisboa constituía-se definitivamente como espaço central e pólo aglutinador da nobreza. O pe. Raphael Bluteau, nos primeiros anos do século XVIII, definia corte como o "lugar aonde reside o Rey, assistido dos Oficiaes, \& Ministros da Casa Real', e também "o palácio real, ou como Ihe chamamos Corte Real, \& todo aquele magnífico composto da família, cortesãos, \& grandezas de um Príncipe". ${ }^{17}$ Essa definição evidenciava com clareza a dupla função que a corte tinha na época: ao mesmo tempo era o lugar central da governação e a casa do rei. Explicitava-se, deste modo, o que já há muito se discutiu a respeito da simbiose que existia entre as esferas pública e privada no âmbito da sociedade do Antigo Regime. ${ }^{18}$ Nesse espaço singular, travavam-se cotidianamente as disputas pela graça régia, pois conforme sintetizou António Camões Gouveia, naquela altura "a casa real alargava-se aos cortesãos", que se constituíam num misto de servidores do rei, dos seus familiares ou do aparelho de Estado, e "que viviam perto para os servir e para Ihes validar a acção enquanto detentores do poder.

do Sacramento na época da sucessão de Espanha. Coimbra: Faculdade de Letras da Universidade de Coimbra/ Instituto de Estudos Históricos, 1973; CLUNY, Isabel. A Guerra de Sucessão de Espanha e a Diplomacia Portuguesa. Penélope. Revista de História e Ciências Sociais, Lisboa, n.26, p.63-92, 2002; ALMEIDA, Luís Ferrand de. D. Luís da Cunha e a idéia de diplomacia em Portugal. Lisboa: Livros Horizonte, 1999; MARTINEZ, Pedro Soares. História diplomática de Portugal. Lisboa: Editorial Verbo, 1992; ORTIZ, Antonio Dominguez. Sociedad y estado en el siglo XVIII español. Barcelona: Ariel, 1990. Para uma visão de conjunto desses fenômenos, ver MOUSNIER, Roland e LABROUSSE, Ernest. O século XVIII: o último século do Antigo Regime. In: CROUZET, Maurice. (dir.) História geral das civilizações. Rio de Janeiro, Bertrand, 1995, vol XI, p.253-364; ZELLER, Gaston. Les Temps Modernes II - De Louis XIV à 1789. In: RENOUVIN, Pierre. (dir.) Histoire des relations internationales. Du Moyen Âge à 1789. Paris: Hachette, 1994, tomo III, v.I, p.493-779; RODRÍGUEZ, Manuel Rivero. Diplomacia y relaciones exteriores en la Edad Moderna. De la cristandad al sistema europeo, 1453-1794. Madrid: Alianza, 2000 ; BÉLY, Lucien. Les relations internationales en Europe. (XVIIe.-XVIIIe. siècles). Paris: Presses Universitaires de France, 1998 ; BÉLY, Lucien. Casas soberanas y orden político en la Europa de la paz de Utrecht. In: ALBALADEJO, Pablo Fernández. (ed.) Los Borbones. Dinástia y memória de nación en la España del siglo XVIII. Madrid: Casa Velázquez - Marcial Pons, 2001, p.69-95. BÉRANGER, Jean. "Los Habsbourgo y la Sucessión de España". In: ALBALADEJO, Pablo Fernández. (ed.) Los Borbones, p.46-68.

16 ARAÚJO, Ana Cristina. Ritualidade e poder na corte de d. João V. A gênese simbólica do regalismo político. Revista de História das Idéias, p.175-208.

17 BLUTEAU, Pe. Raphael. Corte. In: Vocabulário portuguez \& latino. Coimbra: Colégio das Artes da Cia de Jesus 1712, tomo II, p.575-576.

18 ELIAS, Norbert. A Sociedade de corte. Rio de Janeiro: Jorge Zahar Editor, 2001 
Viviam na corte ciosos do amor que do rei podiam receber, manobrando intrigas e formas de aproximação ao centro da corte". ${ }^{19}$

Deste modo, nas dependências do paço da Ribeira funcionavam os órgãos diretamente relacionados com a governação, ou seja, os diversos conselhos, secretarias e ainda as diversas juntas que foram surgindo ao longo dos séculos XVII e XVIII. Nessas instâncias governativas imperavam os dignitários da nobreza tradicional. Com passar do tempo, cada vez mais, elementos oriundos do terceiro estado, como foi o caso de Gusmão, ascendiam por meio dos serviços especializados junto à burocracia. A corte também era o lugar de moradia do rei e sua família, e com eles uma imensa quantidade de servidores, cortesãos, isto é, homens nobres, que seguiam a "corte, servindo, ou assistindo à pessoa real" ${ }^{20}$ Basicamente existiam dois grupos de servidores atuando na dimensão palatina da corte. Em termos estatutários, os chamados ofícios maiores eram aqueles que compreendiam os serviços da nobreza, enquanto os menores ou inferiores relacionavam-se com as condições das profissões mecânicas, o que thes colocava em um estatuto notadamente abaixo. ${ }^{21}$ Essa relação entre o rei e seus servidores, tecida no interior da vida palatina, foi retratada de forma interessante em um escrito do princípio do século XVIII:

He obrigação dos Vassalos empregarem-se no serviço dos Monarchas que os governão, e dos Reys o conserva llos em paz, e justiça, e a huns, e outros he recíproca esta correspondência política de que nenhum dever esquecer, sem expor se ao justo reparo da Censura. ${ }^{22}$

No que se refere aos conselhos palatinos, vale lembrar que tinham raízes mais antigas na tradição política portuguesa e, durante a dinastia bragantina, cada vez mais, assumiram uma posição meramente consultiva, deixando para as Secretarias o papel deliberativo. Estas se constituíram durante o período dos Felipes e, como anotou José Subtil, em 1602 havia quatro secretários que cuidavam do serviço de despacho e correspondiam às áreas do governo central: negócios de estado e justiça, Consciência e ordens, fazenda, além da secretaria de petições e mercês. Em 1607, o número de secretarias diminuiu para dois, sendo que em 1631 surgiu a Secretaria da Índia e Conquistas. Nos primeiros três anos da Restauração, passou a existir somente um secretário de estado, até que dom João IV, por meio do Alvará de 29 de novembro de 1643, viesse a regular as atribuições desta secretaria e criando uma segunda chamada das Mercês e Expediente,

19 GOUVEIA, António Camões. Estratégias de interiorização da disciplina, p.419.

20 BLUTEAU, Pe. Raphael. Cortezam. In: Vocabulário portuguez \& latino, 1712, tomo II, p.577.

21 CARDIM, Pedro. O poder dos afetos. Ordem amorosa e dinâmica política no Portugal do Antigo Regime. Lisboa: Universidade Nova de Lisboa, 2000, p.487 e segs. (História, Tese de Doutorado).

22 Lisboa. Biblioteca Nacional de Lisboa. (BNL). Coleção pombalina, cód 151, f.7. 
que deveria cuidar das "restantes consultas, despachos e ordens", com o objetivo de facilitar o despacho régio. Em fins do século XVII, surgiu uma terceira secretaria, intitulada Assinatura. ${ }^{23}$ Mais tarde, dom João V criará outras quatro secretarias. Em síntese, tal como em outras partes da Europa, no Portugal do Antigo Regime, a vida política característica engendrou uma forma de governação profundamente marcada pelos valores domésticos de entreajuda, em que sempre se percebeu com maior ou menor ênfase aquilo que se convencionou chamar de visão sinodal de governo, em que os ministros e conselheiros tinham um papel ativo no âmbito central do poder. ${ }^{24}$ Nesse contexto, a consulta aos conselhos palatinos e as rotinas decisórias de caráter coletivo foram sempre encaradas como a melhor forma de tomar decisões, algo profundamente acalentado principalmente pela grande aristocracia, conforme vimos. Pedro Cardim, a esse respeito, sinalizou que,

a corte se assentava, assim, numa teia de relações fortemente personalizadas entre o senhor - neste caso, o monarca - e aqueles que o serviam, ou seja, a parte melhor da comunidade, e tais relações eram marcadas por informalidade, por afetividade entre as partes envolvidas e pelo predomínio de uma cultura de serviço onde os valores da lealdade e da fidelidade pessoal estavam no primeiro plano. (...) o afeto e a gratidão do rei..$^{25}$

Os ofícios maiores ou menores e os demais aspectos de funcionamento da casa real, bem como a sua etiqueta e cerimonial, foram estabelecidos e primeiramente normatizados pelo Regimento da Casa Real de D. João $N^{26}$ de 3 de Janeiro de 1643, embora tivessem importante antecedente no modelo organizativo da casa de Bragança, ${ }^{27}$ a qual, por sua vez, se inspirava na casa real de Portugal, anterior a $1580 .{ }^{28}$ Podemos também afirmar que a experiência da união dinástica produziu na nobreza portuguesa uma tendência a incorporar em seu habitus elementos que provinham efetivamente da corte de Madrid, sobretudo no que se refere a códigos de etiqueta e de funcionamento palatino. Segundo Pedro Cardim, o Regimento de 1643 foi de suma importância, pois significou a refundação da própria corte portuguesa, ${ }^{29}$ que desde 1582, Lisboa deixara de contar com

23 SUBTIL, José. Os Poderes do Centro. In: MATTOSO, José. (dir.) HESPANHA, António Manuel. (coord.) História de Portugal. O Antigo Regime (1620-1807). Lisboa: Estampa, 1992, p.178 e segs.

24 HESPANHA, António Manuel. Às véperas do Leviathan. Instituições e poder político em Portugal - XVII. Porto: Almedina, 1994

25 CARDIM, Pedro. O Poder dos afetos, p.557

26 Regimento da Casa Real de D. João IV. Apud: SOUSA, D. António Caetano de. Provas da história genealógica da casa real portuguesa. Coimbra: Atlântida/Livraria Editora, MCMLII, tomo IV.

27 Regimento dos Officiaes da Casa do Duque Dom Theodosio I. Apud: SOUSA, D. António Caetano de. Provas da História genealógica da casa real portuguesa, tomo IV, parte I, p.235-261. Apud: CUNHA, Mafalda Soares da. Redes clientelares da casa de Bragança (1560-1640). Lisboa: Estampa, 1997, p.274.

28 CARDIM, Pedro. O poder dos afetos, p.486.

29 CARDIM, Pedro. O poder dos afetos, p.481 e segs. 
a presença do monarca residente, fato que, embora houvesse durante o período filipino nessa cidade a residência de Vice-Reis ou Governadores, a qual contava com uma capela real, um sistema de moradias e também com um expediente de remuneração de serviços, semelhante à morada de um rei, faltava uma personagem crucial: "o pater famílias, o chefe da casa, o monarca". 30

Portanto, no período específico que nos interessa, Lisboa era reconhecidamente tanto o lugar da casa do rei como também o centro administrativo da governação de todo o reino e das conquistas. Pólo de atração da alta nobreza, a corte durante o longo reinado de dom João $V$ aprofundou o processo de redefinição de seus cerimoniais e cristalizou a hierarquia palatina de forma sofisticada, cuja ritualidade do cerimonial obedecia a rígidos códigos que aprofundavam as diretrizes estabelecidas no Regimento da Casa Real. Outro importante instrumento para a normatização da dinâmica palatina e da Corte foi o Cerimonial da corte de D. Pedro II, ${ }^{31}$ provavelmente redigido no início do século XVIII, que fixava as formas de representação e de assistência aos ofícios da capela real; as precedências e regras protocolares a observar na recepção dos secretários, ministros de Estado e Embaixadores. O Cerimonial normatizava também os códigos de reverência que se deveria seguir em audiências, bem como as regras de etiqueta a observar nas refeições do rei e nos assuntos relativos à câmara do rei. ${ }^{32}$ Todavia, como referimos atrás, o caminho consagrado pela historiografia esteve, desde há muito tempo, marcado pela idéia de que o período joanino foi sinônimo de absolutismo. Porém, nas duas últimas décadas, principalmente, uma recente corrente investigativa tem posto em discussão a natureza do objeto Antigo Regime como problema historiográfico, propondo inúmeras outras formas de se compreender o período. Um dos resultados mais interessantes diz respeito ao questionamento do caráter centralizador e absoluto do poder. Indaga-se que, longe de ser um conceito acabado, a idéia de absolutismo é muito mais um fruto da imaginação ideológica que praticamente não percebeu haver inúmeras outras instâncias normativas ordenando a vida e conferindo coesão social aos diversos grupos que formavam o corpo da monarquia. ${ }^{33}$ Esferas de poder atuavam como forças que, historicamente, dificultavam o processo de afirmação definitiva das amarras da intervenção total do poder régio em todas as instâncias da vida social. Se o argumento através do qual o absolutismo de dom João V se

30 CARDIM, Pedro. O poder dos afetos, p.483-484. A ausência do rei durante essa época foi objeto de importantes estudos específicos como são os estudos de Fernando Bouza Alavarez e Jean-Frederic Schaub. Ver ainda: MEGIANE, Ana Paula Torres. O rei ausente: imagem e memória da monarquia filipina nas jornadas e entradas régias de Portugal (1581-1619). São Paulo: Alameda, 2004.

31 BNL. Cód. 8810, Cerimonial da Corte de D. Pedro II.

32 ARAUJO, Ana Cristina. Ritualidade e poder na corte de d. João V, p.188.

33 XAVIER, Ângela Barreto \& HESPANHA, António Manuel. A representação da sociedade e do poder. In: HESPANHA, António Manuel. (coord.) História de Portugal. O Antigo Regime (1620-1807), p.121-156. 
assenta em coisas do tipo: a não convocação das cortes ao longo de todo seu reinado ou a construção de uma ritualidade cerimonialística suntuosa que visava atingir no plano imaginário à afirmação de um poder absoluto, além das visões típicas do liberalismo oitocentista, sobre o obscurantismo e autoritarismo do regime, pensamos que pesa contra ele a necessidade de se considerar o sistema sinodal que caracterizava a estrutura do estado. Havia um mosaico de poderes. Outro sinal disso que estamos comentando é que existia verdadeiro desconhecimento sobre a natureza específica do território do reino, questão essa para as dificuldades de centralização e controle por parte do Estado. Segundo pesquisou Ana Cristina Nogueira da Silva, essa situação começou a ser resolvida em fins do século XVIII. ${ }^{34}$ Enfim, como assinalou António Manuel Hespanha referindo-se ao final do século anterior, mas que certamente sofreu poucos modificações no seguinte, podemos dizer que

o aparelho administrativo da coroa era muito débil, (...). Dos cerca de 1.700 oficiais que a coroa tinha ao seu serviço..., uns 500 estavam na Corte. No resto do país, apenas 10\% das estruturas administrativas pertenciam à coroa, o que quer dizer que, para cerca de 12.000 funcionários concelhios, senhorias e de outras entidades [excluídos, em todo o caso, os oficiais eclesiásticos], havia 1.200. ${ }^{35}$

O conjunto dessas questões nos faz imaginar os limites da ação do poder central. ${ }^{36}$ Além disso, imaginar o que estamos chamando de poder central, quando este efetivamente existia, representado pela figuração social típica da corte régia, é uma tarefa que deve considerar que o exercício do poder era extremamente complexo, pois, como sintetizou Norbert Elias, "tudo o que vinha das vastas possessões reais, de todas as partes do reino, tinha que passar pelo filtro da corte antes de chegar ao rei; e tudo o que vinha do rei tinha que passar pelo filtro da corte antes de chegar ao país". E, seguindo ainda o pensamento do autor: "Mesmo o monarca mais absoluto só podia atuar sobre o seu país através da mediação dos indivíduos que viviam na corte". Desta maneira, "a corte e a vida na corte constituíam o local originário de toda a experiência, de toda a compreensão do homem e do mundo por parte do rei absolutista do Ancien Régime". ${ }^{37}$

Não obstante, cabe recordar que, em sintonia ao que ocorreu noutras partes da Europa durante o século XIX, a tradição do liberalismo português ajudou a consolidar uma imagem notadamente negativa do Antigo Regime,

34 SILVA, Ana Cristina Nogueira da. O modelo espacial do estado moderno. Reorganização territorial em Portugal nos finais do Antigo Regime. Lisboa: Estampa, 1998

35 HESPANHA, António Manuel. As estruturas políticas em Portugal na Época Moderna. In: TENGARRINHA, José (org.) História de Portugal. São Paulo: Unesp/EDUSC, 2003, p.127.

36 Destacamos aqui os trabalhos de António Manuel Hespanha, Nuno Gonçalo Monteiro e Pedro Cardim para o caso português; Bartolomé Clavero, Pablo Fernandez Albaladejo e Xavier Gil Pujol para o caso espanhol. No seu conjunto, estes autores apontam para o caráter complexo e, por assim dizer, descentralizado do Estado Moderno.

37 ELIAS, Norbert. A sociedade de corte, p.67. 
em particular o reinado de dom João V (1707-1750). Vista como uma época marcada pela forma absolutista de reinar, identificando o rei como freirático, luxurioso, soberbo e tirânico, por esse viés explicativo, o período joanino conheceu críticas mordazes de autores como Oliveira Martins e Antero de Quental, dentro daquilo que se convencionou chamar de "decadentismo" - fenômeno típico de certos setores da elite letrada portuguesa, principalmente a partir da segunda metade do século XIX. ${ }^{38}$ Pode-se mesmo dizer que, durante um bom espaço de tempo, a historiografia portuguesa fez tabula rasa dessa época, tratando-a de forma menor, ao contrário de outros períodos como foram os séculos XV e XVI, compreendidos então como o apogeu dos povos peninsulares. Bom exemplo disso encontramos na História de Portugal, publicada pela primeira vez em 1879, em que Oliveira Martins dizia que dom João $V$ fora um rei débil: "ao mesmo tempo de balofo e carola"39 - tradução de uma completa inércia na condução da governação. Esse estado de coisas faz com que as riquezas que volumosamente chegavam da América se dissipassem rapidamente devido à manutenção da etiqueta palatina e da devoção religiosa, cuja construção do convento de Mafra traduziu-se no melhor exemplo da falta de racionalidade na gestão do reino. Pouco tempo antes, Antero de Quental, em conferencia lida em 1871, dizia que na Península, durante os séculos XVII, XVIII e XIX, havia um "quadro de abatimento e insignificância", em sensível contraste "com a grandeza, a importância e a originalidade que desempenhamos no primeiro período da renascença, durante toda a Idade Média e ainda nos últimos séculos da Antiguidade". 40

Essa visão "negativa" da época, marcadamente do reinado de dom João V, permaneceria presente nas obras de autores importantes como Antonio Sérgio ${ }^{41}$ e João Lúcio de Azevedo, ${ }^{42}$ durante as primeiras décadas do século passado. Por sua vez, o destacado historiador português, Jaime Cortesão, que exerceu certa influencia na historiografia brasileira, inseriu-se nessa mesma perspectiva tempos mais tarde, principalmente na biografia de Alexandre de Gusmão. ${ }^{43}$ Resumidamente, podemos dizer que para esses autores somente os aspectos que se enquadrassem nas idéias de modernidade e aproximassem Portugal de determinadas proposições ilustradas

38 Sobre esta questão gostaríamos de indicar as seguintes leituras: RESENDE, Maria Aparecida Resende Mota. Brasil e Portugal: imagens da nação na geração de 70 do século XIX. Rio de Janeiro: UFRJ/IFCS/PPGHIS, 1998. (História, tese de Doutorado); TORGAL, Luís Reis; MENDES, José Amado; CATROGA, Fernando. História da História em Portugal. Séculos XIX-XX. A História através da História. Lisboa: Temas \& Debates, 1998, v.I.

39 MARTINS, J. P. Oliveira. História de Portugal. Lisboa: Livraria Editora, 1920, v. II, p.152; MARTINS, J. P. Oliveira. Historia de la civilizacion Iberica. Buenos Aires: El Ateneo, 1951

40 QUENTAL, Antero de. Causas da decadência dos povos ibéricos. Lisboa: Ulmeiro, 1987, p.14

41 SÉRGIO, Antonio. O reino cadaveroso ou o problema da cultura em Portugal. In: Ensaios. Lisboa: Sá da Costa, 1972, tomo II, p.25-61; SÉRGIO, Antonio. Breve interpretação da História de Portugal. Lisboa: Sá da Costa, 1989.

42 AZEVEDO, João Lúcio. Marquês de Pombal e a sua época. São Paulo: Alameda, 2004. (1ª. Edição de 1909); AZEVEDO, João Lúcio. Épocas de Portugal econômico. Lisboa: Clássica Editora, 1988. (1ª. Edição de 1929).

43 CORTESÃO, Jaime. Alexandre de Gusmão e o Tratado de Madrid. Rio de Janeiro: Ministério das Relações Exteriores, 1955, parte I, tomos I e II. 
mereceriam destaque. Na falta disso, fazia-se e denunciava-se a ausência. Assim, produziu-se uma imagem no mínimo distorcida do período, o que dificultou sobremaneira uma compreensão daquela época mais afastada dos preconceitos típicos de análises que insistem em impor juízos de valor contemporâneos a épocas pretéritas. Não que o quadro de poder e opressão impostos pela Inquisição e pelo conservadorismo que caracterizava a formação social portuguesa no período, o atraso econômico, não fossem realidades muito presentes naquela época. Por sinal, eram questões analisadas e severamente criticadas por personagens importantes do período como pe. Antonio Vieira, Manuel Severim de Faria e Duarte Ribeiro de Macedo, no século XVII, dom Luís da Cunha, José da Cunha Brochado e Alexandre de Gusmão, dentre inumeros outros ao longo do século XVIII. O problema é que esta forma de entender o período acabou impedindo que houvesse uma compreensão pautada na historicidade que estas questões possuíam em seu tempo, o que levou a inevitáveis reducionismos.

Recentemente, entretanto, no veio investigativo que se configurou o estudo das nomeadas sociedades de corte modernas, principalmente a partir da recepção da obra de Norbert Elias pelo público de língua portuguesa, tem sido objeto importantes estudos. ${ }^{44} \mathrm{O}$ grande diferencial dessa nova forma de olhar o problema é a tentativa de compreender as sociedades do Antigo Regime como uma realidade radicalmente diversa das atuais, como um novo continente cultural, para usar uma expressão de cunho antropológico. Nesse ínterim, tanto o reinado joanino como a sociedade portuguesa de uma forma mais ampla são objetos de novas problematizações, apontando para uma mudança qualitativa no enfoque que passou a primar pela historicidade das práticas, das representações, das instituições, das idéias e da cultura política. Por esse viés, vieram à luz importantes estudos sobre o absolutismo, a corte e a imagem política de dom João V. Temáticas como as regras de etiqueta que regulavam a vida cortesã, a festa, arquitetura de poderes, o cerimonial fúnebre, o retrato do rei, a diplomacia e as práticas de governo no reino, dentre outras questões, constituem-se nos tópicos fundamentais para a compreensão da monarquia portuguesa na primeira metade do século XVIII. ${ }^{45}$

Um trabalho pioneiro foi o pequeno estudo de Rui Bebiano, intitulado D. João V. Poder e espetáculo. ${ }^{46}$ Nele, o autor concentrou suas atenções no processo de construção/fabricação da imagem de dom João V. Para tanto analisou o uso declaradamente político do espetáculo e da festa como

44 A primeira edição da obra A Sociedade de corte para a língua portuguesa data de 1987, publicação feita pelo Editorial Estampa de Portugal.

45 Agradecemos a Professora Doutora Ana Cristina Araújo, do Instituo de História das Idéias, da Universidade de Coimbra, por ter nos apresentado essa historiografia.

46 BEBIANO, Rui. D. João V. Poder e espetáculo. Aveiro: Estante Editora, 1987. 
instrumentos, a partir de categorias típicas da cultura barroca. ${ }^{47}$ Bebiano demonstrou como que as grandes encenações públicas, diretamente relacionadas ao universo áulico, funcionavam como formas de glorificação da monarquia e perpetuação da memória do rei. Neste sentido, outro aspecto que tem recebido merecida atenção é a problemática que gira em torno do culto à pessoa régia. Luís Manuel Ramalhosa Guerreiro ${ }^{48}$ e Ana Cristina Araújo $^{49}$, citada anteriormente, aprofundaram essa questão relacionando o cerimonial e a ritualidade no âmbito do processo de construção do poder monárquico. Aqui, da mesma forma, as festividades e o cerimonial foram objetos de análise, porém sob um ponto de vista notadamente relacionada à liturgia do poder em sua dimensão religiosa. A temática da morte do rei é importante nesses estudos. Seguindo o caminho investigativo iniciado por Ernest Kantorowicz, ${ }^{50}$ Ralph Giesey ${ }^{51}$ e Sergio Bertelli, ${ }^{52}$ essa historiografia tem procurado demonstrar todos os problemas relacionados à morte e a ausência, mesmo que momentânea, do rei. Deste modo, tanto Guerreiro quanto Ana Araújo problematizaram os níveis de incerteza e as tensões que perpassavam todo tecido social durante esses eventos, posto que todo o conjunto da sociedade de corte portuguesa representava-se ali.

Destarte, a análise de temáticas relacionadas ao campo das artes, como a arquitetura e a pintura, insere-se nesse quadro historiográfico e também produziu bons resultados, e tem permitido perceber as estratégias pelas quais essas duas atividades estiveram intimamente relacionadas à própria fabricação da imagem régia nesse período..$^{53}$ Assim, conforme sugere António Filipe Pimentel, a preocupação com a espacialidade simbiótica da casa régia com o templo religioso de Mafra fornece rico veio para a discussão dos mecanismos mais profundos da construção do poder do rei. ${ }^{54}$ Enfim, esse conjunto de estudos, o qual citamos aqui somente uma pequena parte, tem procurado superar as idiossincrasias que marcaram as percepções historiográficas sobre o período durante boa parte dos dois últimos séculos,

47 MARAVALL, José Antonio. La cultura del Barroco. Barcelona: Ariel, 1990.

48 GUERREIRO, Luís Manuel Ramalhosa. La représentation du povoir royal à l' age barroque portugais (1687-1753). Paris: École des Hautes Études en Sciences Sociales, 1995, 4vols. (História, tese de doutorado)

49 ARAÚJO, Ana Cristina. Ritualidade e poder na corte de D. João V, p.175-208.

50 KANTOROWICZ, E. Os dois corpos do rei. São Paulo: Cia das Letras, 1998.

51 GIESEY, Ralph E. Le roi ne meurt jamais. Les obseques royales dans la France de la Renaissance. Paris: Flammarion, 1987

52 BERTELLI, Sergio. // corpo de/ re. Sacralità del potere nell `Europa medievale e moderna. Firenze: Ponte Alle Grazie, 1995, p.39-57.

53 Ver PIMENTEL, António Filipe. Arquitetura e poder. O real edifício de Mafra. Coimbra: 1992; FRANÇA, José-Augusto. O Retrato na Época Joanina. In: SALDANHA, Nuno. (coord.) JOANI V MAGNIFICO, Catálogo da Exposição: A pintura em Portugal no tempo de D. João V, 1706-1750. Lisboa: 1994; FRANÇA, José-Augusto. Absolutismo, corte e palácio real. Em torno dos palácios de D. João V. In: Arqueologia do Estado. Comunicações 2. Lisboa: História \& Crítica, 1988, p.685-710.

54 PIMENTEL, António Filipe. Arquitetura e poder, p.220-227. 
buscando perceber novos objetos e novos problemas, sugerindo novas formas de abordagem que nos são importantes mencionar. ${ }^{55}$

No plano complexo das questões relativas à cultura e ao pensamento político, à dinâmica institucional, à administração e ao funcionamento da corte portuguesa durante os Bragança, entre os séculos XVII e XVIII, as análises de António Manuel Hespanha, ${ }^{56}$ Nuno Gonçalo Monteiro, ${ }^{57}$ Pedro Cardim, ${ }^{58}$ Ângela Barreto Xavier ${ }^{59}$ e Maria Fernanda Olival, ${ }^{60}$ quase todas já referidas anteriormente, constituem-se nos melhores exemplos de como a historiografia tem se empenhado em investigar os aspectos mais particulares da organização social, jurídica e política do período que estamos tratando. Esses autores permitem-nos compreender as minúcias da configuração social portuguesa, a saber: o jogo palatino, as estratégias aristocráticas de acrescentamento, a disputa pelo amor régio, as formas de internalização das normas, enfim, uma gama de questões que viabilizam alarga nossa compreensão dessa outra sociedade e dessa outra cultura política. Sem dúvida, a partir dessas pesquisas, o estudo das elites e da sociedade do Antigo Regime português vem ganhando novo fôlego. ${ }^{61} \mathrm{E}$ isto nos permite

55 No que se refere à historiografia brasileira, além da obra clássica de Francisco Falcon, A Época Pombalina, destacamos os seguintes estudos quem recentemente, abordam questões relacionadas à Corte e ao período Joanino: BICALHO, Maria Fernanda. A cidade e o império. O Rio de Janeiro na dinâmica colonial portuguesa, séculos XVII e XVIII. Rio de Janeiro: Civilização Brasileira, 2003; MONTEIRO, Rodrigo Bentes. O rei no espelho. Monarquia portuguesa e a colonização da América 1640-1720. São Paulo: Hucitec, 2002; ROMEIRO, Adriana. Um visionário na corte de D. João V. Revolta e milenarismo na Minas Gerais. Belo Horizonte: Ed.UFMG, 2002; KANTOR, Íris. De esquecidos e renascidos: a Historiografia acadêmica lusoamericana (1724-1759). São Paulo: HUCITEC, 2005.

56 António Manuel Hespanha, sem dúvida, exerce um papel de liderança nesse grupo de investigadores. Dentre as suas diversas obras, destacamos: HESPANHA, António Manuel. Às vésperas do Leviathan; HESPANHA, António Manuel. História de Portugal. O Antigo Regime (1620-1807; HESPANHA, António Manuel. As estruturas políticas em Portugal na Época Moderna, p.117-181.

57 MONTEIRO, Nuno Gonçalo. Os conselhos e as comunidades. In: HESPANHA, António Manuel. (coord.) História de Portugal. O Antigo Regime (1620-1807), v.IV, p.303-331; MONTEIRO, Nuno Gonçalo. Poder senhorial, estatuto nobiliárquico e aristocracia. In: HESPANHA, António Manuel. (coord.) História de Portugal. O Antigo Regime (16201807), v.IV, p.333-379; MONTEIRO, Nuno Gonçalo. Ethos da aristocracia portuguesa sob a dinastia de Bragança. Revista de História das Idéias, Coimbra, v.19, p.383-402, 1997; MONTEIRO, Nuno Gonçalo. O crepúsculo dos grandes. A casa e o patrimônio da aristocracia em Portugal (1750-1832). Lisboa: Imprensa Nacional/Casa da Moeda, 1998; MONTEIRO, Nuno Gonçalo. A consolidação da dinastia de Bragança e o apogeu do Portugal barroco: centros de poder e trajetórias sociais (1668-1750). In: TENGARRINHA, José. (org.) História de Portugal, p.127-149.

58 Ver CARDIM, Pedro. Cortes e cultura política no Portugal do Antigo Regime. Lisboa: Edições Cosmos, 1998; CARDIM, Pedro. Centralização política e Estado na recente historiografia sobre o Portugal do Antigo Regime. Nação e Defesa, v.87, 2a série, p.129-158, outono de 1998; CARDIM, Pedro. Religião e ordem social. Em torno dos fundamentos católicos do sistema político do Antigo Regime. Revista de História da ldéias, Coimbra, v.22, p.133-174, 2001; CARDIM, Pedro. Memoria Comunitaria y Dinámica Constitucional en Portugal (1640-1750). In: ALBALADEJO, Pablo Fernández. (ed.) Los Borbones. Dinástia y memória de nación en la España del siglo XVIII, p.117-140; CARDIM, Pedro. Entradas Solenes: rituais comunitários e festas políticas, Portugal e Brasil, séculos XVI e XVII. In: JANCSÓ, István e KANTOR, Íris. (orgs.) Festa: Cultura e sociedade na América Portuguesa. São Paulo: Hucitec/Edusp/Fapesp, 2001, v.l, p.97-126; CARDIM, Pedro. A Casa Real e os órgãos centrais de governo no Portugal da segunda metade de Seiscentos. Tempo, v.7, n.13, p.13-59, jul. 2002.

59 XAVIER, Ângela Barreto. 'El Rei aonde póde \& não aonde quer'. Razões da política no Portugal seiscentista; XAVIER, Ângela Barreto \& HESPANHA, António Manuel. A representação da sociedade e do poder; XAVIER, Ângela Barreto \& HESPANHA, António Manuel. As redes clientelares. A economia do dom. Amizades e clientelas na ação política. In: HESPANHA, António Manuel. (coord.) História de Portugal. O Antigo Regime (1620-1807), p.381-393.

60 OLIVAL, Maria Fernanda de. Honra, mercê e venalidade: as ordens militares e o estado moderno em Portugal (1641-1789). Évora: Universidade de Évora, 1999. (História, Tese de Doutorado).

61 Recentemente a historiadora Maria Beatriz Nizza da Silva escreveu uma biografia de D. João V, obra que integra a coleção Reis de Portugal, da $1^{a}$. à $4^{a}$. dinastia. 
dizer opera-se uma verdadeira metamorfose historiográfica no que tange aos estudos sobre o Antigo Regime português.

\section{As metamorfoses do império}

Mas, deixemos a corte e os problemas de ordem historiográfica indicados, e direcionemos nosso olhar para outra dimensão do mundo português durante a primeira metade do século XVIII. Recordemos que, neste período, notadamente a própria configuração e natureza daquilo que poderíamos chamar de Império Colonial Português ${ }^{62}$ havia mudado substancialmente, pois finalizado o processo de lutas pela independência e restaurado o reino soberano, Portugal já não era nem sombra daquilo que fora em meados do século XVI. As glórias das campanhas no norte da África estavam na memória, mas a tragédia de Alcácer-Quibir e a subseqüente crise dinástica que levou à perda da independência do reino eram lembranças igualmente presentes. ${ }^{63} \mathrm{O}$ estado da India não se constituía mais, na realidade, a fonte de riqueza e honra conforme fora no passado, apesar de, como apontou Nuno Gonçalo Monteiro, os serviços e cargos ligados àquela parte do império continuarem a serem fundamentais nas estratégias de acrescentamento para a alta nobreza. ${ }^{64}$ Operava-se, na prática, uma certa inversão de eixo no império. A esse respeito Eduardo d'Oliveira França, em seu estudo clássico, Portugal na época da Restauração, anotou que "antes o problema era a conquista e o domínio do mar", isto porque, "o Império português no século XVI é um império oceânico, feito de bases marítimas que policiam e apóiam suas relações com os continentes", ${ }^{65}$ algo muito semelhante ao que o historiador português Luiz Felipe Thomaz caracterizou como um processo que "na sua origem, não era mais do que uma rede de rotas marítimas, possuindo apenas, como indispensáveis pontos de apoio em terra, alguns pequenos espaços descontínuos, que só tinham razão de ser em função dessa rede". ${ }^{66}$ Da mesma forma, o historiador brasileiro Eduardo d'Oliveira França, em tese clássica, já observara que

no Oriente, o Império da Índia se desagregava administrativamente e militarmente como uma tapera em ruínas. Aquele rosário litorâneo de fortalezas e empórios de tráfico rompia-se, minado internamente de todos os males da decadência e submergido pelo assalto dos rivais europeus. Gloriosa missão para cavaleiros

62 Ver BOXER, Charles R. O império colonial português. Lisboa: Ed.70, 1981.

63 Ver HERMANN, Jacqueline. No reino do desejado. A construção do sebastianismo em Portugal. Séculos XVI-XVII. São Paulo: Cia das Letras, 1998.

64 MONTEIRO, Nuno Gonçalo. Trajetórias sociais e governo das conquistas: Notas preliminares sobre os vice-reis e governadores-gerais do Brasil e da índia nos séculos XVII e XVIII. In: FRAGOSO, João; BICALHO, Maria Fernanda; GOUVÊIA, Maria de Fátima. (orgs.) O Antigo Regime nos trópicos. A dinâmica imperial portuguesa (séculos XVIXVIII). Rio de Janeiro: Civilização Brasileira, 2001, p.249-283.

65 FRANÇA, Eduardo d'Oliveria. Portugal na época da Restauração. São Paulo: Hucitec, 1997, p.166.

66 THOMAZ, Luís Filipe F. R. De Ceuta a Timor. Lisboa: Difel, 1994, p.259. 
cheios de bom pudor: salvar a donzela - já um pouco madura embora - da sanha dos piratas neerlandesses e britânicos. Posição de defesa. Refrega e mais refregas que não acabavam nunca, recomeçando sempre, porque os portugueses não tinham recursos para varrerem de vez os assaltantes de seus mares. Missão policial apenas. A India era uma fortaleza sitiada. E as brechas se alargavam dia a dia. ${ }^{67}$

Não obstante, no momento em que estamos tratando a configuração atlântica do Império estava delineada, bem como as dependências que só faziam crescer as rendas oriundas do tráfico e demais formas de acumulação mercantil naquela época. Se no primeiro quartel do seiscentos, Frei Vicente do Salvador ${ }^{68}$ e Ambrósio Fernandes Brandão, ${ }^{69}$ por exemplo, reclamavam do descaso com que a América portuguesa era tratada, enquanto que, apesar da flagrante decadência da carreira da Índia, Frei Serafim de Freitas ${ }^{70}$ em 1625, respondendo ao livro Mare liberum, de Hugo Grotius, ainda insistia em justificar e defender a primazia e justeza do império asiático português de forma aparentemente anacrônica, agora, no início do século XVIII era tudo bem diferente. Não era possível mais negar uma nova organização o império colonial.

No transcorrer do século XVII, efetivamente, passou-se de uma ação de conquista e depredação para uma atuação colonizadora. ${ }^{71}$ Neste sentido, a montagem do complexo negreiro-açucareiro no atlântico-sul, ligando as duas margens do oceano, África e Brasil, significou a sincronização das engrenagens do sistema colonial", ${ }^{72}$ garantindo para a coroa a ascendência sobre as rendas. Como sintetizou Kenneth Maxwell: "em fins do século XVII, o foco do interesse imperial de Portugal deslocou-se para o ocidente, abandonando a talassocracia dos postos comerciais do oceano Índico, estabelecida em inícios do século XVI". ${ }^{73}$ Interessante observar que havia clara consciência deste estado de coisas, pois ficava evidente nos escritos que tinham a América portuguesa como objeto no início do século XVIII. No sentido de fazer propaganda das vantagens de olhar para a América portuguesa com maior atenção, frei Antônio do Rosário (1647-1704), em 1702, dizia que "a Índia Oriental há muitos anos, que por pecados e injustiças, já não é Índia, o Brasil, pela cana, pelos bizalhos dos diamantes, que embarca em milhares de caixas todos os anos, é a verdadeira Índia

67 FRANÇA, Eduardo d'Oliveira. Portugal na época da Restauração, p.165.

68 SALVADOR, Frei Vicente do. História do Brasil. 1500-1627. Belo Horizonte/São Paulo: Itatiaia/Edusp, 1984.

69 BRANDÃO, Ambrósio Fernandes. Diálogos das grandezas do Brasil. Rio de Janeiro: Dois Mundos Editora Ltda, 1943.

70 FREITAS, Frei Serafim de. Do justo império asiático dos portugueses. (1ª. edição 1625). Lisboa: Instituto de Alta Cultura, 1959, 2v.

71 FRANÇA, Eduardo d'Oliveira. Portugal na época da Restauração, p.166

72 ALENCASTRO, Luiz Felipe de. O trato dos viventes. A formação do Brasil no Atlântico Sul. Séculos XVI e XVII. São Paulo: Cia das Letras, 2000, p.34.

73 MAXWELL, Kenneth. Hegemonias antigas e novas: o Atlântico ibérico ao longo do século XVIII. In: Chocolate, piratas e outros malandros. Ensaios tropicais. Rio de Janeiro: Paz e Terra, 1999, p.218. 
e mina dos Portugueses". ${ }^{74}$ Pouco tempo depois, de maneira semelhante, em obra de maior expressão, de 1711, o jesuíta André João Antonil (16491716) apontava para uma nova consciência sobre a posição do Brasil na constelação do império, anotando que

não haverá quem possa duvidar de ser hoje o Brasil a melhor e a mais útil conquista, assim para a Fazenda Real, como para o bem público, de quantas outras conta o reino de Portugal, atendendo ao muito que cada ano sai destes portos, que são minas certas e abundantemente rendosas. ${ }^{75}$

Não obstante, em virtude das fragilidades apresentadas pelas monarquias ibéricas durante o século XVIII, fato que, como sugerimos, ficou por demais evidente já na conjuntura da Guerra Espanhola. A emergência de novas potências como Holanda, França e Inglaterra modificaram a lógica concorrencial mercantilista, transformando os países que haviam sido vanguarda na expansão marítima e comercial em estados menores ou zonas semiperiféricas. ${ }^{76}$ Essa patente fraqueza de Portugal diante dessas potências dificultava a tarefa de garantir o império - fundamentalmente o complexo Atlântico e a América portuguesa. Nesse ponto, um documento já citado inúmeras vezes é luminoso: a Consulta do Conselho Ultramarino a S. M., feita pelo conselheiro Antônio Rodrigues da Costa, em 1732, que, ao denunciar a delicada posição de Portugal no concerto das nações, anotou o seguinte: "os tratados de pazes, que temos com as nações marítimas da Europa, nos não podem dar segurança alguma de que não empreenderão sobre nós, para se senhorearem de tesouros tão ricos", fazendo com que fosse muito "duvidosa e arriscada a conservação daquele Estado"77 - isto é, o Brasil. Conforme percebia Rodrigues da Costa, três perigos rondavam o domínio sobre as conquistas do Estado do Brasil: o primeiro era externo, isto é, a violência e a força que poderiam fazer as outras nações; o segundo provinha dos naturais e vassalos, isto é, os ditos perigos internos; ${ }^{78} \mathrm{e} \mathrm{o}$ terceiro, que é fruto da aliança entre a força externa e a vontade e interesse da força interna dos mesmos vassalos. Noutra passagem desse precioso documento, a vulnerabilidade de se guardarem as riquezas do Brasil era apontada devido, concretamente, aos seguintes fatores:

74 ROSÁRIO, Frei António do. Frutas do Brasil. Numa nova e ascética monarquia, consagrada à Santíssima Senhora do Rosário. Lisboa: Officina de Antônio Pedrozo Galram, 1702, p.51.

75 ANTONIL, André João. Cultura e opulência do Brasil. Belo Horizonte/São Paulo: Itatiaia/Edusp, 1982, p.205.

76 Sobre essa questão ver: WALLERSTEIN, Immanuel. O sistema mundial moderno. Porto: Edições Afrontamento, 1990, 2vs.

77 COSTA, Antônio Rodrigues da. Consulta do Conselho Ultramarino a S. M., no ano de 1732. Revista do Instituto Histórico e Geográfico Brasileiro, Rio de Janeiro, n.28, tomo VII, p.475-476, 1931.

78 Ver: MELLO, Evaldo Cabral de. A fronda dos mazombos. Nobres contra mascates. Pernambuco. 1666-1715. São Paulo: Cia das Letras, 1995. 
os nossos riquíssimos tesouros do Brasil se acham tão mal guardados, que apenas têm algumas praças de defesas na Marinha, porque, sendo esta tão larga, não é possível fortificar-se: além de que esta pouca e má fortificação é de tal natureza e condição, que lhe pode suceder muito naturalmente que, sem o pensar, ache sobre si, de um dia para outro, uma armada: e vemos que no Rio de Janeiro, sendo investido duas vezes pelos franceses, de ambas foi entrada a cidade; e da primeira, ainda que os inimigos eram só setecentos, esteve em evidentíssimo perigo de ser saqueada; e da segunda foi também entrada, e Ihe foi necessário evitar parte do saque a peso de ouro, e perdemos todos os navios que tínhamos no porto, de guerra e mercantes; que foi outra perda muito considerável. E os holandeses nos tomaram a Bahia no ano de 1620 com mui pequenas forças, sem Ihes serem necessário mais que saltarem na terra. Destes sucessos se deixa bem ver o grande perigo em que estão aqueles tesouros, porque nem o Rio, nem a Bahia, nem os mais portos e marinha, se acham hoje com melhor fortificação que tinham quando foram entradas aquelas praças, que, ainda que se mandaram fortificar, apenas se tem dado princípio às fortificações, nem elas, ainda que acabadas, poderiam evitar o golpe de serem entradas e saqueadas; e ultimamente dominadas por uma cidadela, que se mandou fazer em cada uma poderá resistir mais alguns dias; mas, finalmente, se há de render por falta de víveres. ${ }^{79}$

Com impressionante clarividência, o conselheiro assinalava toda a vulnerabilidade da América portuguesa - situação em que se encontrava também o próprio reino no velho continente. Como já falamos anteriormente, a história das relações externas de Portugal na época moderna foi marcada por um permanente clima de medo e insegurança. Garantir as colônias, ou seja, a principal fonte de riquezas do império ultramarino, era condição sine qua non à própria existência de Portugal como estado soberano. Nesse ponto, observemos a sentença que se encontra na Consulta: "Bem se deixa ver que, posto em uma balança o Brasil, e na outra o Reino, há de pesar com grande excesso maior aquela que esta". 80

Destarte, na História genealógica da Casa Real portugueza, desde a sua origem até o presente, com as famílias ilustres, que procedem os Reys, e dos Sereníssimos Duques de Bragança, obra monumental publicada no decênio de 1740, considerada como marco simbólico fundamental para a legitimação da memória do reinado de dom João V, Antonio Caetano de Sousa também resumiria a importância do Brasil na configuração do império que apresentava sob o afã da riqueza americana.

No seu tempo se começarão a colher copiosissimos tributos das Minas Geraes, entranhadas no Certão do Brasil, que no reynado del Rey seu pay tiverão principio, como dissemos, e elle mandara pocoar, a que concorreo em pouco tempo tanta gente, que edifiarao Villas, e Aldeãs (...). No seu reynado, a que propriamente

79 COSTA, Antônio Rodrigues da. Consulta do Conselho Ultramarino a S. M., no ano de 1732, p.476. 80 COSTA, Antônio Rodrigues da. Consulta do Conselho Ultramarino a S. M., no ano de 1732, p.482. 
se pode chamar o Século do Ouro, se continuou a tirar das Minas abundante copia de ouro, de que se seguirão outras importantíssimas em diversas partes no mesmo continente da América Portugueza no Estado do Brasil" . ${ }^{81}$

Essa nova realidade se evidenciava com o fluxo das riquezas provenientes da mineração nos sertões do Brasil, descobertas entre a última década do século XVII e no princípio da segunda década do século XVIII, que, conforme anotaram frei Antônio do Rosário e Antonil, trouxeram à coroa a necessidade de reformular sua orientação política de forma ampla, buscando fortalecer os laços com a colônia e redefini-la do ponto de vista político e territorial. O reinado de dom João $\vee$ foi marcado pelo empenho em realizar estas árduas tarefas. Para tanto, e ao contrário daquilo que a historiografia do século XIX enfatizou, o estado português, por meio dos agentes que estavam encarregados da governação, conferiu racionalidade e não mediu esforços e recursos para alcançar seus objetivos. Garantir o Brasil era garantir o reino independente diziam várias personalidades de suma importância no período, como é o caso de dom Luís da Cunha. ${ }^{82}$

Observado tudo isso, deve-se considerar que, no plano interno, ocorria plena sedução da nobreza, o que possibilitou expressiva estabilidade, facilitada pelo afluxo das riquezas do Brasil que, no dizer de outro contemporâneo, causava "admiração da Europa as frotas do Brasil pela riqueza que transportam da América", tesouros a tanto aguardados e que se "manifestaram liberalmente em seu reinado" ${ }^{83}$ o que permitiu operar com grande margem de manobra na implementação de projetos e atender mais confortavelmente às demandas intrínsecas à governação do reino, fazendo com que fosse visto por todos como um monarca sabidamente generoso. A esse respeito, o mesmo Antonio Caetano de Sousa dizia que dom João V era "de uma incomparável generosidade, de que manão [sic] torrentes da sua real liberalidade". ${ }^{84}$ A governação Joanina, como vimos, manteve o modelo político que privilegiava a participação da alta nobreza junto aos conselhos, porém a participação decisiva de validos e favoritos inseridos no âmago do exercício de poder denota uma tentativa de afirmar sua centralidade e ao

81 SOUSA, Antonio Caetano de. Historia genealógica da casa real portugueza. Coimbra: Atlântida/Livraria Editora, 1741, tomo VIII, p.111.

82 Nesse ponto, a visão de D. Luis da Cunha aponta para o cerne da questão a partir da ousada proposta de transferência da cabeça da Monarquia para a América naquela conjuntura, dizendo: "qual a residência para a monarquia será mais vantajosa, aquela em que pode viver precariamente esperando ou temendo, que cada dia o queiram despojar do seu diadema ou aquela em que pode dormir o seu sono descansado e sem algum receio de que o venham inquietar? Problema que em duas palavras resolvo dizendo, que o dito príncipe para poder conservar Portugal necessita totalmente das riquezas do Brasil e de nenhuma maneira das de Portugal, que não tem para sustentar o Brasil, de que se segue, que é mais cômodo e mais seguro estar onde se tem o que sobeja, que onde se espera o de que se carece". CUNHA, dom Luís da. Instruções inéditas a Marco Antônio de Azevedo Coutinho. Coimbra: Academia de Ciências de Lisboa/Imprensa da Universidade, 1929, p.217-218. Ver: OLIVEIRA, Ricardo de. Política, diplomacia e o império colonial português na primeira metade do século XVIII. História: Questões \& Debates, Curitiba, n.36, p.251-278, 2002.

83 SOUSA, Antonio Caetano de. Historia genealógica da casa real portugueza, tomo VIII, p.111-112.

84 SOUSA, Antonio Caetano de. Historia genealógica da casa real portugueza, tomo VIII, p.177. 
mesmo tempo aponta para o fortalecimento da burocracia palatina, esta na maior parte dos casos formada de elementos de uma pequena nobreza ou mesmo de não nobilitados, o que, devido à complexificação das estruturas do estado, sugere a existência de uma efetiva porosidade. Neste sentido, produzia-se no seio da corte uma tensão permanente entre esses grupos que, apesar de não formarem "partidos", fomentavam um jogo de intrigas e disputas para obter a centralidade da graça régia. Entretanto, nenhum dos validos de dom João $V$ chegou a monopolizar sozinho seu afeto. Eis talvez a habilidade desse monarca em fazer valer de forma tão intensa o mecanismo régio de que dispunha para conduzir a monarquia.

Devemos assinalar também que, conforme Fernando Novais já há algum tempo chamava a atenção, no que se refere à gestão, por assim dizer, das relações internacionais, dom João $V$ se cercou sempre dos talentos mais preciosos que possuía Portugal na época, tendo como representantes do reino, nas principais monarquias européias, os talentos mais destacados: dom Luís da Cunha, conde da Tarouca, José da Cunha Brochado, Sebastião de Carvalho e Melo, dentre outros. ${ }^{85}$ Desse modo, nos assuntos ligados à gestão interna do reino, é inegável que, por mais centralizador que tenha sido a sua práxis governativa, dom João $V$ contou sempre com a opinião e o zelo de figuras importantes que o cercavam, gerindo de fato a máquina da burocracia do estado. ${ }^{86}$ Enfim, conforme analisou Francisco Falcon, "trata-se de uma época singular, esta que precede à viragem política e ideológica de meados do século XVIII". ${ }^{87}$ Pugnavam-se o velho e o novo: o esplendor barroco e o fanatismo devoto; dependência econômica, política com tentativas de autonomia; propostas que podem ser compreendidas dentro daquilo que se convencionou denominar reformismo ilustrado, com perspectivas notadamente conservadoras, mas que dialogaram com o que se passava no campo das idéias no resto da Europa. Podemos mesmo dizer que o mundo português, à sua maneira, vivenciou os problemas básicos dessa crise, que se manifestava em questões filosóficas, religiosas e éticas pela qual a inteligência européia passou entre fins do século XVII e o início do XVIII, criando soluções próprias para os problemas que Ihe surgiam. Vale assinalar que o reinado joanino, nesse particular, apesar de toda repressão e fechamento intelectual promovidos pela autoridade religiosa, e por causa disso, foi um período marcado pela ambigüidade e, tal como em outras partes da Europa, pelo conflito entre o velho e o novo.

85 NOVAIS, Fernando. Política de Neutralidade. In: Portugal e Brasil na crise do Antigo Sistema Colonial (1777-1808). São Paulo: Hucitec, 1982, p.28 e segs.

86 ALMEIDA, Luís Ferrand de. O absolutismo de D. João V. In: ALMEIDA, Luís Ferrand de. Páginas dispersas. Estudos de História Moderna de Portugal. Coimbra: Faculdade de Letras/Instituto de História Económica e Social, 1995, p.183 e segs.

87 FALCON, Francisco. A época pombalina. São Paulo: Ática, 1982, p.203. 